УДК 069: $061.4(571.150)+3$

DOI 10.37386/2687-0592-2020-10-342-350

\title{
И. И. Назаров
}

Алтайский государственный университет, г. Барнаул, Российская Федерация

\section{Этнографическая выставка в современном музейном пространстве Барнаула ${ }^{1}$}

Аннотация. В публикации презентуется опыт организации и проведения этнографических выставок на различных площадках города Барнаула. Выставки проводились по двум основным тематическим направлениям: первое связано с презентацией коллекции традиционных головных уборов народов мира из коллекции автора этой публикации, второе актуализировало этнографическую коллекцию по культуре коренных народов Северного Алтая из фондов Музея археологии и этнографии Алтая Алтайского государственного университета. Выставки получили положительные отклики различных групп посетителей и широко освещались в различных средствах массовой информации. Успешность выставок была связана и с их активным продвижением в социальных сетях. Ключевые слова: этнография, музей, выставки, коллекционирование, головные уборы, Центральная Азия, Северный Алтай.

Современная практика этнографической и музейной работы наделена новыми инструментами, дающими уникальную возможность создания кратковременных проектов, обеспеченных информационной поддержкой СМИ и выходом на большую аудиторию, в том числе в социальных сетях. В этой публикации анализируется опыт проведения подобных выставочных проектов с этнографической тематикой, которые в течение последних трех лет реализовывались г. Барнауле на разных площадках при участии автора этой публикации.

Наша работа по организации этнографических выставок проводилась по двум тематическим направлениям. Первое из них было связано с презентацией коллекции традиционных головных уборов народов мира, собранных автором этой публикации. Второе направление отразило изменение парадигмы деятельности Музея археологии и этнографии Алтая Алтайского государственного университета, который в последние годы активизировал выставочную деятельность на своей площади. В контексте этого изменения стало возможным оформление выставки по этнографии, отразившей коллекцию предметов по традиционной культуре аборигенных групп Северного Алтая.

Рассмотрим опыт реализации выставочных проектов по двум указанным выше направлениям, которые, как показала практика, оказались востребованными у посетителей и получили широкое освещение средствах массовой информации. Из-за введенных в марте 2020 г. ограничительных мер в деятельности музеев из-за угрозы распространения новой коронавирусной инфекции выставочные проекты получили свое закономерное продолжение в социальных сетях

1 «При подготовке публикации использованы материалы гранта РГНФ, проект 13-01-00170 а - «Геоинформационный мониторинг уязвимых компонентов этнокультурной среды в местах традиционного проживания и хозяйственной деятельности коренных малочисленных этносов Алтае-Саянского региона».
Проведению всех выставок, о которых будет сказано ниже, предшествовала активная кампания продвижения в СМИ и в популярных социальных сетях. В последнем случае в социальных сетях «ВКонтакте» и «Facebook» создавались тематические мероприятия, которые с помощью доступных инструментов обеспечивали приглашение гостей на открытие выставок. В специально созданных группах в социальных сетях и личных аккаунтах автора этой статьи в ходе работы выставок публиковались информационные материалы о выставках, их посетителях, а также о планируемых акциях. Информационная кампания в интернет-пространстве обеспечила привлечение большого числа посетителей, а также способствовала формированию устойчивого интереса к этнографической проблематике.

\section{Опыт презентации частного собрания}

На протяжении уже почти 10 лет автор этой публикации осуществляет целенаправленных сбор головных уборов, отражающих этнические традиции народов мира. Наша увлеченность центральноазиатскими традиционными головными уборами берет начало в 2011 г. Именно тогда наш коллега Д. А. Глазунов подарил узбекскую тюбетейку. Со временем увлеченность постепенно переросла в профессиональный интерес, сопровождающийся системным поиском головных уборов в разных частях планеты.

В настоящее время коллекция размещается в рабочем кабинете автора публикации в Алтайском государственном университете (АлтГУ). Коллекция пополняется во время поездок автора в страны ближнего зарубежья, благодаря подаркам коллег, а также в ходе поиска и заказа интересующих головных уборов через социальные сети. На момент написания этой статьи в коллекции имелось уже более 150 уборов, отражающих этнические традиции 50 народов из 25 стран мира. При этом самая представительная часть коллекции отражает все же центральноазиатские традиции: казахов, киргизов, туркмен, таджиков и узбеков.

Поскольку коллекция, разрастаясь, перестала помещаться в небольшом рабочем кабинете, возни- 


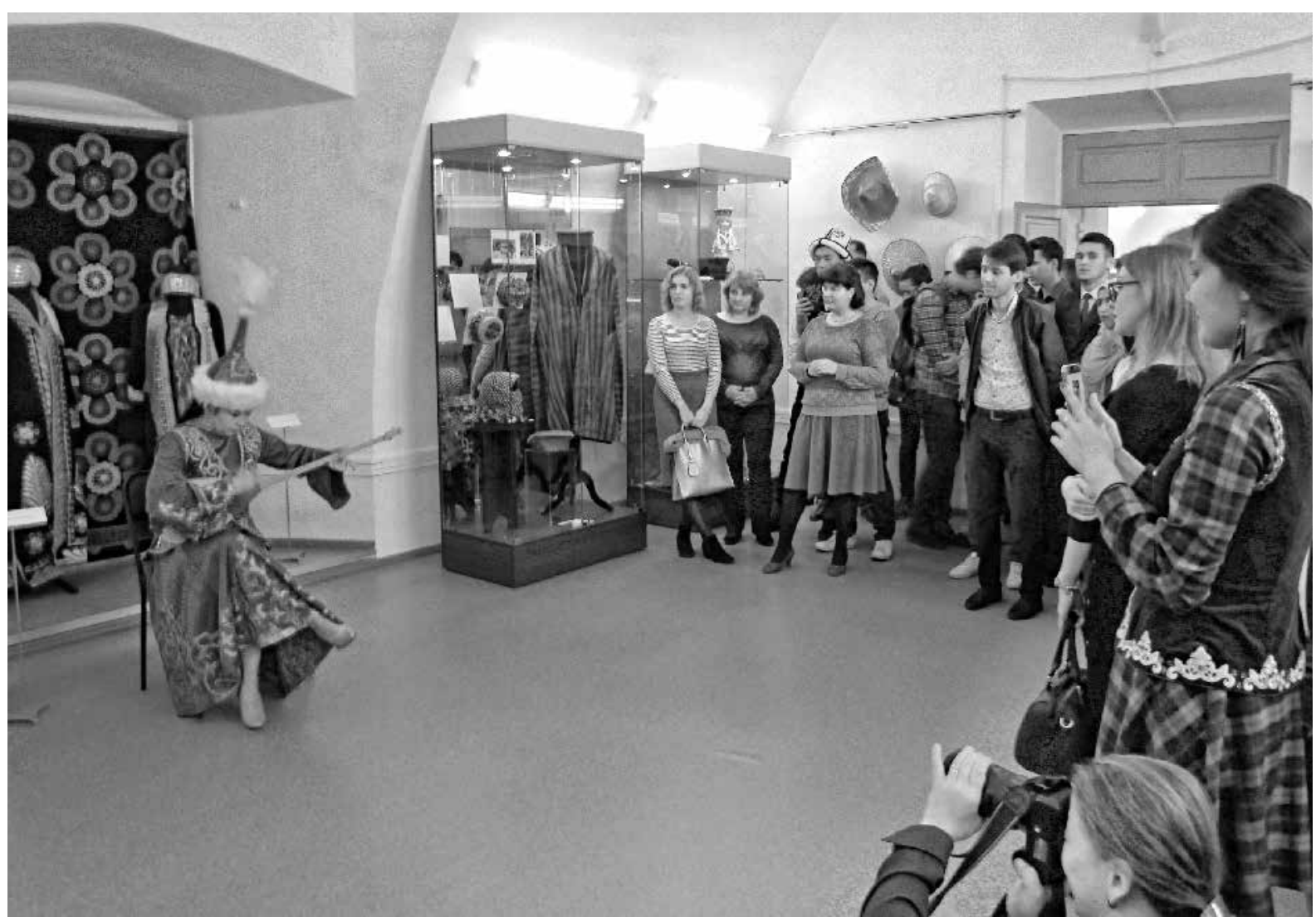

Рис. 1. Открытие выставки «Все дело в шляпе» в Алтайском государственном краеведческом музее в октябре 2018 г. Фото из архива автора.

кла идея о ее обнародовании, презентации на выставочных площадках города. До этого автор рассказывал о коллекции в социальных сетях: «Facebook», «Instagram», «ВКонтакте» и «Одноклассники». Положительные отклики и комментарии к тематическим постам о коллекции подтвердили интерес общества к такому выставочному проекту.

В 2018 г. идея презентации национальных головных уборов нашла поддержку у нового руководства Алтайского государственного краеведческого музея (АГКМ), включившего наш проект в график выставок на новой площадке музея по адресу ул. Ползунова, 39. Проект был реализован в октябре 2018 г. Он получил название «Все дело в шляпе» и объединил в экспозиции около сотни предметов из частной коллекции и предметы из фондов АГКМ. Соединение в рамках одной экспозиции музейных коллекций и предметов из нашего личного собрания позволило представить для зрителей развитие головных уборов разных национальных групп на протяжении целого столетия [1-3].

Существенную помощь в организации, монтаже и открытии выставки оказали сотрудники АГКМ Л. С. Супонина и Д. В. Емельянов, получившие специализированное образование на историческом факультете АлтГУ. За все время работы выставку посетили несколько сотен человек. Для организованных групп школьников были проведены экскурсии. Выставка «Все дело в шляпе», не имевшая анало- гов среди выставочных проектов на музейных площадках г. Барнаула, привлекла живой интерес региональных СМИ, которые подготовили об этом проекте серию газетных публикаций [4-7], а также передачу на радио [8].

Второй выставочный проект под название «Из сердца Азии: символика национальных головных уборов» был реализован весной 2019 г. на базе Алтайского краевого Российско-немецкого дома в г. Барнауле и был поддержан правительством Алтайского края. В рамках этого проекта на выставке были представлены более семидесяти головных уборов из разных регионов Азии [9-14]. В его реализации оказали помощь студенты исторического факультета АлтГУ, обучавшиеся по направлению подготовки «Музеология и охрана объектов культурного и природного наследия». Данная выставка была нацелена на демонстрацию разнообразия хозяйственных, культурных, и религиозных особенностей азиатских народов [15].

Учитывая специфику выставочной площадки Российско-немецкого дома, больший интерес к выставке «Из сердца Азии: символика национальных головных уборов» был проявлен со стороны национально-культурных организаций Алтайского края и студентов высших учебных заведений г. Барнаула. Для них автором коллекции проводились экскурсии по выставке. В ходе самой выставки, работа которой по просьбам посетителей неоднократно про- 


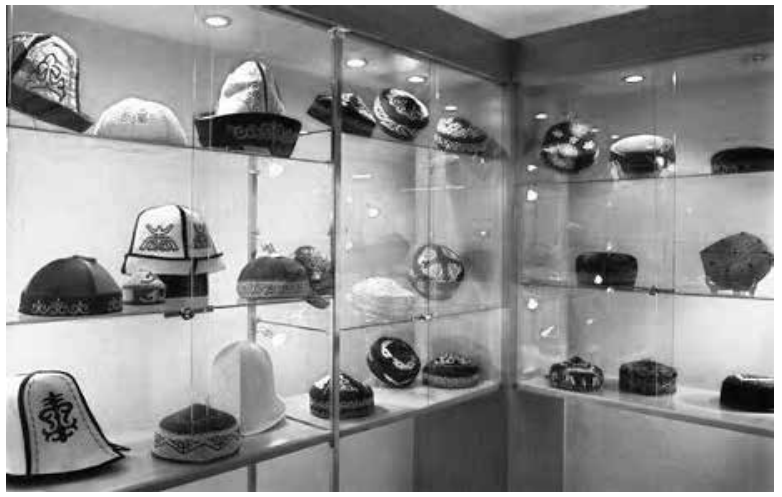

Рис. 2. Выставка «Из сердца Азии: символика национальных головных уборов» в Алтайском краевом Российско-

Немецком доме, март 2019 г. Фото из архива автора.

длевалась [16], коллекция азиатских головных уборов пополнилась десятю предметами, подаренными благодарными экскурсантами.

Третий выставочный проект был реализован в феврале 2020 г. в галерее «Универсум» Алтайского государственного университета. Он носил название «Ритмы Центральной Азии: многоголосье головных уборов». Его открытие было приурочено к проведению в АлтГУ международной стратегической сессии «Развитие международного сотрудничества в Центрально-Азиатском научно-образовательном и культурном пространстве: опыт и лучшие практики» [17]. На выставке в четырех витринах были размещены пятьдесят традиционных и современных мужских и женских головных уборов народов Центральной Азии: казахов, кыргызов, монголов, таджиков, туркмен, узбеков и уйгуров [18-22].

В оформлении выставки ее организаторам оказали помощь студенты исторического факультета АлтГУ, обучающиеся по новому направлению под- готовки бакалавриата «Антропология и этнология». Эта выставка стала для них не только первым опытом музейной работы, но и своего рода учебным пособием, по которому они в рамках учебной дисциплины «Антропология и этнография народов мира» смогли познакомиться с материальной культурой центральноазиатских народов.

Выставку в момент ее открытия посетили иностранные гости участники стратегической сессии, а в последующие недели интерес к ней был проявлен со стороны студентов алтайских вузов, жителей и гостей Барнаула. Дальнейшей работе выставки, однако же, помешали ограничительные мероприятия, связанные с пандемией.

\section{Университетский музей и этнографические выставки}

Второе направление выставочной деятельности связано с актуализацией историко-культурного наследия коренного населения Северного Алтая, которое отложилось фондах Музея археологии и этнографии Алтая АлтГУ. Этнографическая коллекция университетского музея формировалась на протяжении многих десятилетий в ходе экспедиционного изучения сотрудниками АлтГУ южных [23] и северных групп [24] коренного населения Алтая. В числе хранящихся в музее предметов, отражающих традиционную культуру аборигенов Алтая, преобладают посуда и утварь, орудия труда, средства передвижения и культовые объекты [25].

В плане этнокультурной принадлежности большая часть музейных предметов отражает традиционную культуру кумандинцев, тубаларов, челканцев и шорцев - коренных малочисленных народов, проживающих в районах Северного Алтая. Основу их традиционной системы жизнеобеспечения в прошлом составляла зимняя таежная пешая охота, ско-

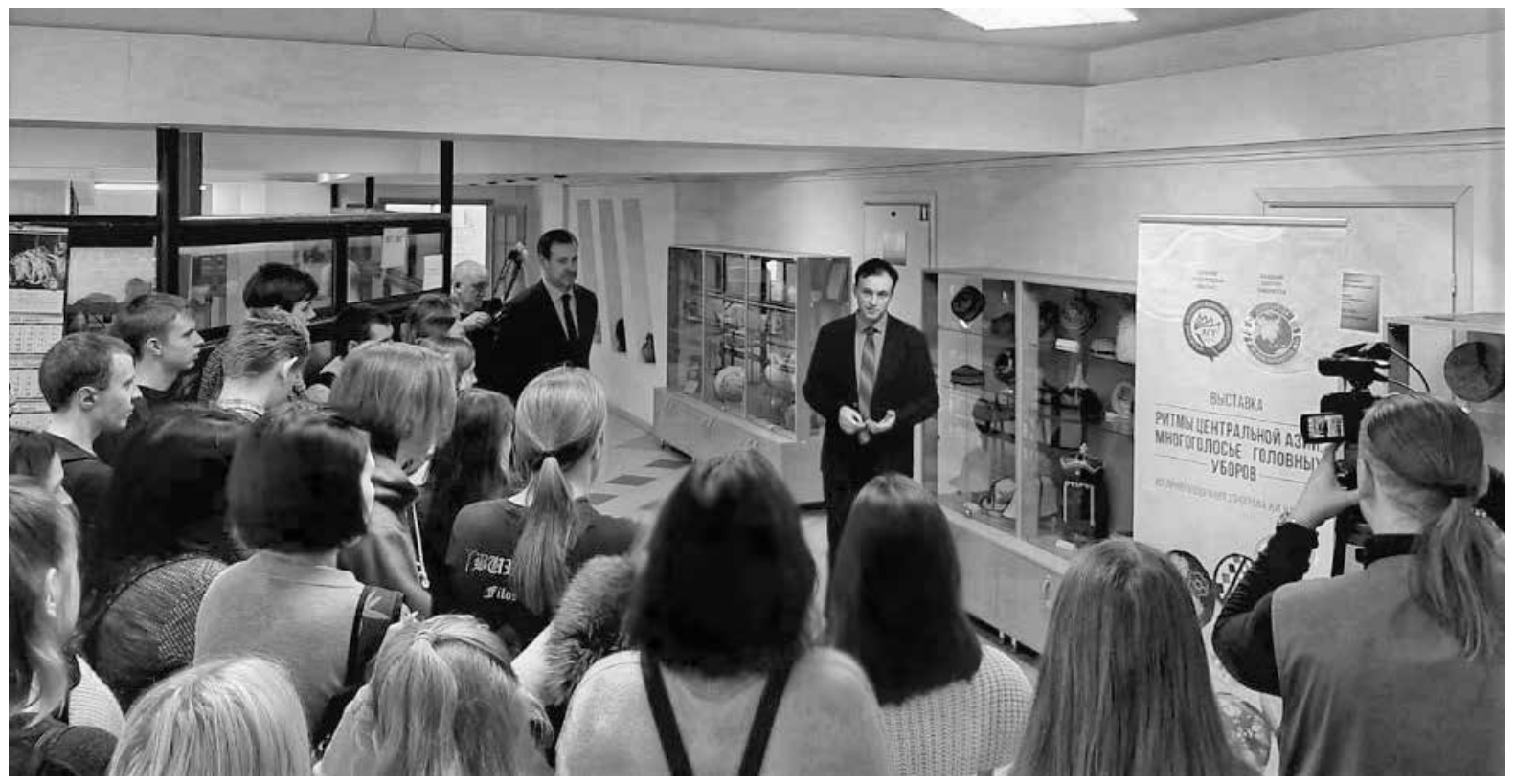

Рис. 3. Открытие выставки «Ритмы центральной Азии: многоголосье головных уборов» в галерее «Универсум» в Алтайском государственном университете в феврале 2020 г. Фото из архива автора. 


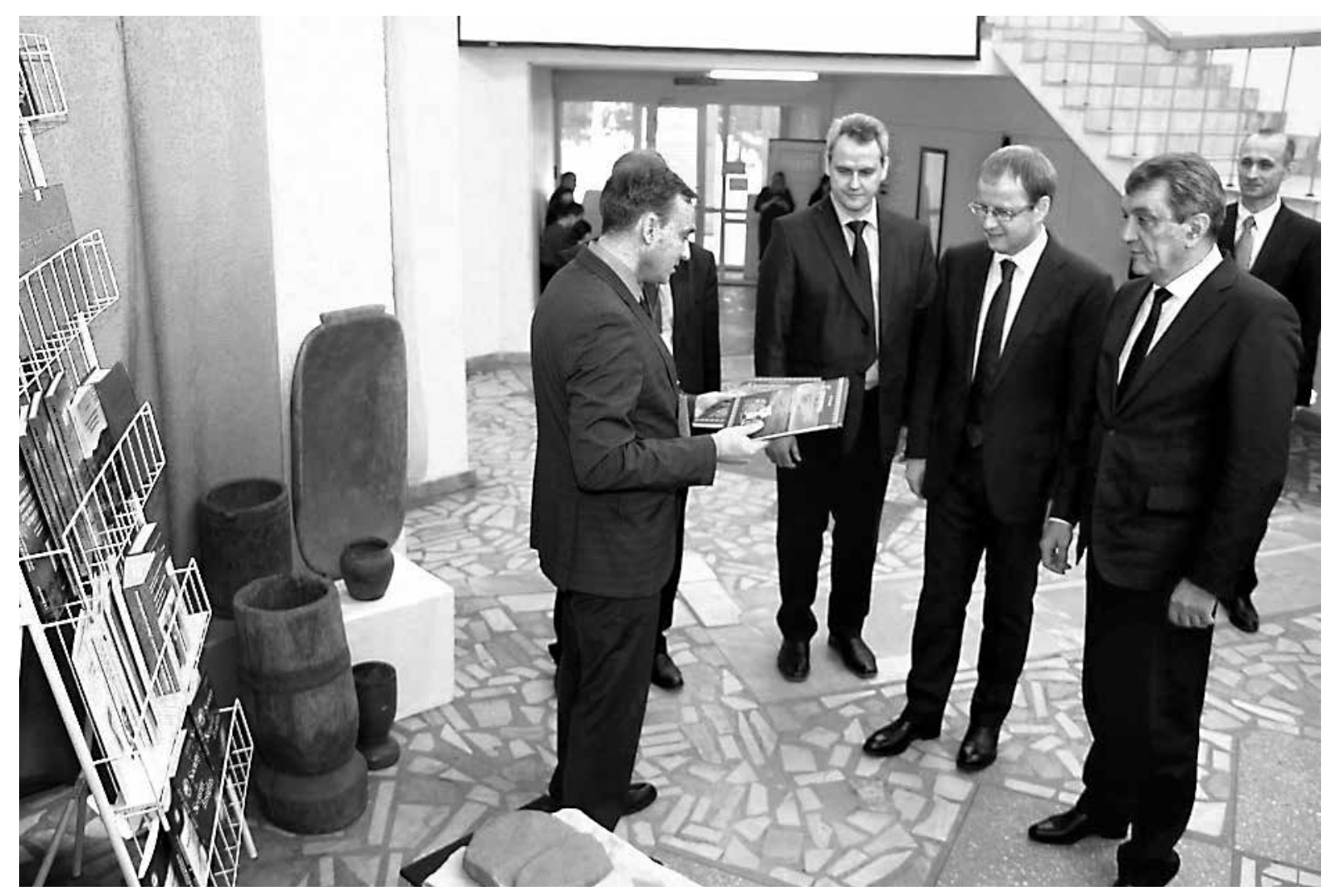

Рис. 4. Выставка «Культура народов Северного Алтая» и ее первые посетители: ректор АлтГУ С. Н. Бочаров, губернатор Алтайского края В. П. Томенко, Полномочный представитель Президента РФ в Сибирском федеральном округе С. И. Меняйло, 3 декабря 2019 г. Фото из архива автора.

товодство и мотыжное земледелие с сопутствующими домашними ремеслами, обеспечивающими производство предметов утвари и посуды. Осмысление предметов, имеющихся в этнографических фондах Музея археологии и этнографии Алтая? позволило разработать проект небольшой выставки, раскрывающей особенности традиционной культуры северных алтайцев. В разработке выставки, помимо автора этой статьи, принимал участи и директор названного музея кандидат исторических наук Я. В. Фролов.

Пилотная версия этой выставки была презентована в АлтГУ 3 декабря 2019 г. в рамках заседания экспертно-консультативного совета по делам коренных малочисленных народов Севера, Сибири и Дальнего Востока Российской Федерации. Первыми ее посетителями стали полномочный представитель Президента Российской Федерации в Сибирском федеральном округе С. И. Меняйло, губернатор Алтайского края В. П. Томенко, члены экспертно-консультационного совета, а также представители коренных малочисленных народов Северного Алтая [26].

В дальнейшем выставочный проект о культуре северных алтайцев был доработан и реализован на площадке самого Музея археологии и этнографии Алтая АлтГУ. Торжественное открытие выставки, получившей название «Мир таежных культур Северного Алтая», состоялось 13 февраля 2020 г. при участии руководства АлтГУ, представителя Правительства Алтайского края и членов кумандинской националь- но-культурной организации. Размещенные на выставке предметы и иллюстративные материалы позволили показать особенности традиционного охотничьего и скотоводческого быта северных алтайцев, их материальной и духовной культуры [27-29].

Представленные на выставке «Мир таежных культур Северного Алтая» уникальные предметы, в том числе кумандинские охотничьи лыжи и скульптура духа-покровителя охоты Шалыга, привлекли внимание городских СМИ, подготовивших о проекте газетные и радиоматериалы [30, 31, 32]. В ходе организованных посещений выставки в феврале и марте 2020 г. были проведены экскурсии для студентов барнаульских вузов.

Работа выставки, как и деятельность самого Музея археологии и этнографии Алтая, оказалась с середины марта 2020 г. свернутой из-за мер, направленных на ограничение распространения новой коронавирусной инфекции. Ограничение в работе музея сопровождалось и переходом всего образовательного процесса в АлтГУ на дистанционную форму. В рамках дистанционного преподавания для студентов АлтГУ учебных дисциплин «Историческая этнография Сибири» и «Этнология» автор этой статьи привлекал внимание обучающихся к выставке по культуре северных алтайцев серией публикаций в социальных сетях. Тематические публикации и посты под общей рубрикой «История одного экспоната», сопровожденные популярными текстами и гале- 
реями фотографий, превратили ушедшую в виртуальное пространство выставку «Мир таежных культур Северного Алтая» в образовательный ресурс, оказавшийся востребованным у студентов.

Приведем несколько примеров таких публикаций в личном аккаунте автора этой статьи в сети «Facebook».

\section{История первая. Дух-покровитель охоты}

Шалыг. 27 февраля 2020 г.

В самом начале XXI века я, как и многие мои коллеги-этнографы, разъезжавшие с экспедициями к тюркским народам Южной Сибири, пребывал в полной уверенности, что ничего от традиционной религиозной культуры у этих народов уже и не осталось. Представлялось совершенно несбыточным встретить в какой-либо современной кумандинской семье скульптуру одного из духов-покровителей таежных промыслов...

Наши предшественники, этнографы начала $\mathrm{XX}$ в., еще смогли застать целые пласты архаичной духовной культуры аборигенных групп Сибири. Застали, описали, сфотографировали и наполнили хранилища центральных этнографических музеев страны уникальными образцами ритуальной скульптуры алтайцев, хакасов, сибирских татар...

Казалось, что вихри культурных трансформаций второй половины XX в. напрочь смели последние остатки традиционных религиозно-мифологических представлений и обрядов, а также их материальные воплощения.

И тут представьте: в 2001 г. в доме у пожилой кумандинки Анны Яковлевны Шалтогачевой в селе Сайдып я обнаружил деревянную скульптуру одного из главных духов покровителей кумандинских охотников - Шалыга. Это антропоморфное изображение было изготовлено Яковом Кистаевичем, отцом Шалтогачевой, столетие назад. Яков родился в 1870 г. и со своей семьей жил в аиле Сайлапка, промышлял охотой и особо почитал духа Шалыга. Старушка хранила скульптуру как память о своем отце. Призналась, что подумывала отнести ее в тайгу и оставить там на дереве. Но в ходе беседы со мной она согласилась передать фигурку в музей АлтГУ, при условии, что память об ее отце-охотнике останется. Условие это я и выполняю сегодня.

В экспозиции нашей выставки «Мир таежных культур Северного Алтая» скульптура Шалыга, изготовленная в начале XX в. кумандинским охотником Яковом Кистаевичем Шалтогачевым - один из центральных экспонатов. Он помогает понять основы традиционной картины мира таежных охотников Северного Алтая.

По собранным у кумандинцев в начале XX в. сведениям изображение Шалыга (который, кстати, мог иметь и другие имена) хранилось в домах охотников. Накануне охоты промысловики устраивали жертвоприношения Шалыгу, «кормили» его специально приготовленной брагой или кашицей, камлавшие шаманы обращались к нему с молитвами-прошениями. В ходе самого промысла и по его оконча- нии также приносились жертвы Шалыгу, устраивались совместные трапезы.

Согласно кумандинским легендам, Шалыг являлся внуком самого бога Ульгеня. Дед послал Шалыга к людям, чтобы тот жил среди них, оберегал от злых духов, помогал им в охоте и способствовал общему благополучию. По другим легендам, Шалыг приходился племянником или даже младшим сыном того же Ульгеня. Он жил на восходе солнца и ведал всей дичью в тайге. Считалось, что Шалыг невидимым образом сопровождает охотников в тайге. Чтобы отвлечь его внимание, охотники во время промысла рассказывали сказки. Завороженный этими сказками, Шалыг не замечал, как охотники убивали его зверей.

У солтонских кумандинцев записаны сведения, что Шалыг был отчаянным и бесстыдным. Он никого не признавал и без страха ходил даже к богу Эрлику, в доме которого сломал три двери. За это Эрлик решил наказать Шалыга и поставил на тропе заряженный самострел, в который затем и попался Шалыг. Стрела ранила ногу и язык Шалыга. С тех пор Шалыг не может нормально говорить и хромает на одну ногу. Именно поэтому кумандинцы иногда изготавливали скульптуру Шалыга с одной короткой ногой. Шалыг мог оказывать помощь в лечении глазных болезней людей, но мог и «наказать» охотников болезнью спины, ломотой костей.

Аналогичный персонаж и его деревянные скульптурные изображения имелись и у ближайших соседей кумандинцев - шорцев, челканцев и тубаларов.

История вторая. Кумандинские охотничьи лыжи шана. 11 марта 2020 г.

В экспозиции нашей выставки «Мир таежных культур Северного Алтая» центральное место занимают охотничьи камусные лыжи. Камус - это шкура с ног лошади. Такими шкурами и подшиты лыжи. Широкие лыжи являются главным и уникальным явлением культуры таежных групп аборигенного населения Северного Алтая - кумандинцев, челканцев, тубаларов и шорцев. В языках этих народов, относящихся к тюркским, камусные лыжи именуются шана. Алтайский миссионер Василий Вербицкий во второй половине XIX в. писал: «Лыжи употребляются непременно с подволоками... что делается для большей каткости лыж и удобства входить на горы... покачиваясь из стороны в сторону, инородцы на лыжах легко пробегают от 70 до 80 верст в весенний день, а в самый короткий зимний, обыкновенным бегом от 50 до 60 верст. Но если охотнику нужно перехватить зверя... то он пробегает от 100-150 верст в день...». Использование коренными сибирскими народами таких лыж зафиксировано и на фотографиях путешественников начала XX в. Например, на фото Г. И. Иванова 1913 г., явно постановочном фото, мы видим шорского охотника с полным охотничьим снаряжением на лыжах-шана и со специальным посохом в руках. Такой посох-тоек помогал охотнику в беге на лыжах, а также и в охотничьем промысле. 


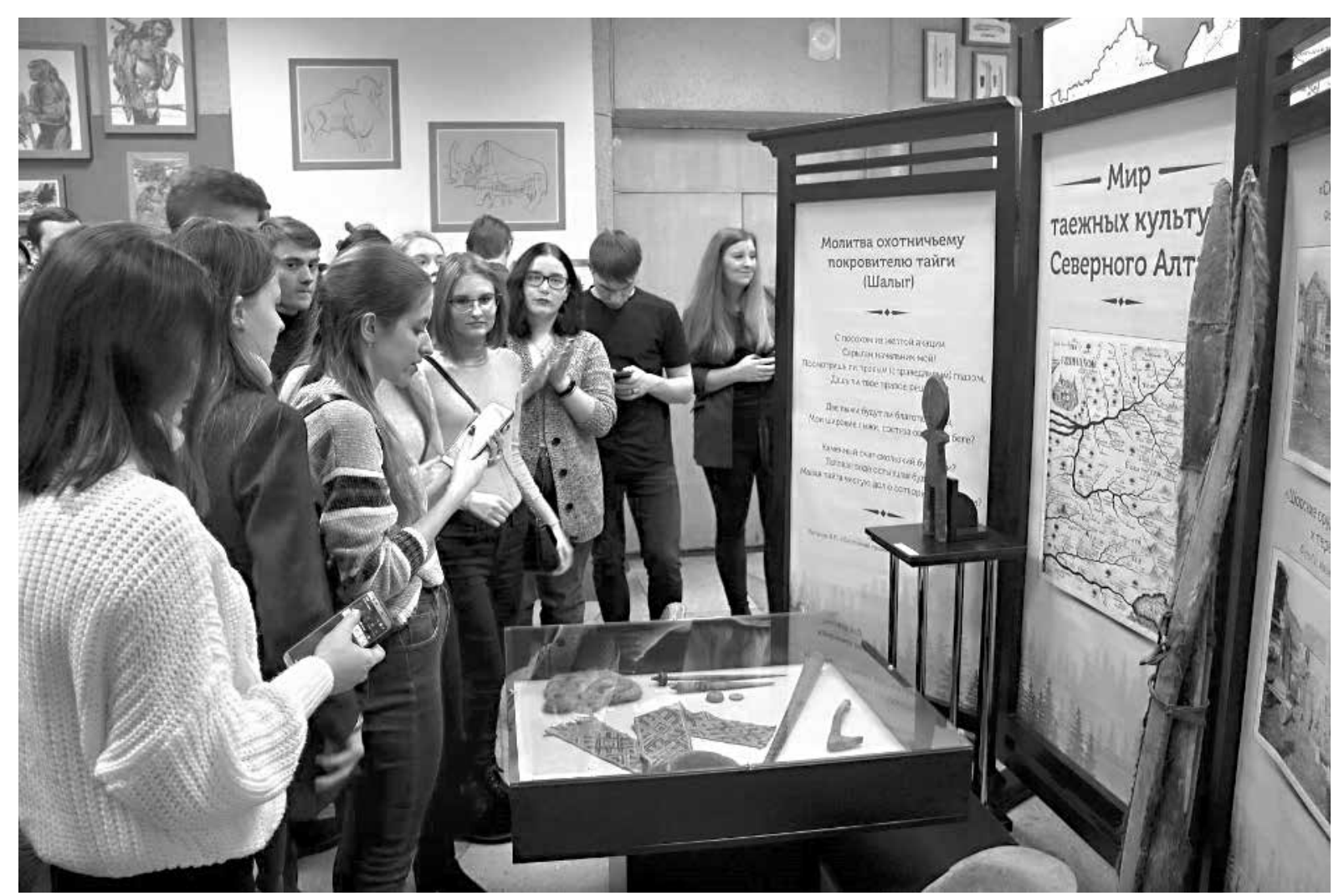

Рис. 5. Открытие выставки «Мир таежных культур Северного Алтая» в Музее археологии и этнографии Алтая в Алтайском государственном университете 13 февраля 2020 г. Фото автора.

Аборигены Алтая использовали и другой тип лыж - так называемые голицы, без меховой подшивки для бега по неглубокому снегу и насту. Без лыж, которые обеспечивали главное занятие населения - охоту, вряд ли бы древние люди освоили горно-таежную зону Северного Алтая. У коренных обитателей этих районов Алтая камусные лыжи и лыжи-голицы встречаются и сегодня.

Пару таких лыж-подволок я встретил в 2002 г. в Солтонском районе в с. Нижняя Ненинка. Их хозяин - Наумушкин Валерий Петрович, которой изготовил лыжи в конце XX в., любезно согласился передать их в наш университетский музей. А я такой счастливый с этими лыжами в тот момент и сфотографировался...

\section{История третья. Кумандинский шерстяной} пояс. 29 марта 2020 г.

В центральной витрине выставки «Мир таежных культур Северного Алтая» располагается фрагмент домотканого шерстяного мужского пояса, который в 2001 г. мы встретили в кумандинской семье в с. Красногорском. Его владелица ранее разделила пояс на три части, из которых планировала сделать коврик. Согласилась один отрез передать в наш Музей археологии и этнографии Алтая.

Подобные пояса встречались и у других коренных народов Южной Сибири. В тюркских языках пояс именуется кур. Тканые из шерстяных нитей пояса являются, по-видимому, уникальным изобретением аборигенов Сибири. Это отражение древних пра- ктик собирательства или выращивания растительного сырья (крапива, конопля, лен), навыков разведения мелкого рогатого скота для получения шерсти, а также технологий изготовления нитей и ткачества. Нити окрашивались при помощи минеральных и растительных красителей. Ткали такие пояса на небольших ручных станках.

У кумандинцев мужские и женские шерстяные пояса различались по ширине. Мужские пояса были широкими, до 15 см и более, а женские пояса были узкими - до 10 см. В длину пояса-кур могли достигать 2-2,5 м. Такая длина позволяла обернуть пояс вокруг талии несколько раз, утепляя и укрепляя верхнюю распашную одежду. Кроме того, сотканный из цветных нитей пояс украшал костюм его владельца.

Размещавшиеся на поясах орнаменты говорили о высоком мастерстве кумандинских ткачих, а также передавали ключевые для народа мировоззренческие установки. На поясе, который представлен на нашей выставке, выткан узор «лягушка» (пого).

У кумандинцев лягушка - это один из важных духов - помощников шамана. Символическое изображение лягушки помещалось и на внешней стороне шаманских бубнов. Считалось, что эти духи помогают шаману нести жертвенную брагу духам-хозяевам гор. Во время камлания шаман обращался к этому духу со словами: «Твои глаза красны, твое пузо толстое, твои ноги кривы. Сможешь ли ты добраться до Ульгеня?»... 
История четвертая. Каменная зернотерка пасак. 2 апреля 2020 г.

На выставке «Мир таежных культур Северного Алтая» в Музее археологии и этнографии Алтая АлтГУ представлен уникальный экспонат - каменная зернотерка. Это устройство предназначено для перемалывания зерен.

Зернотерка - свидетельство долгого и сложного процесса генезиса культуры таежных групп Северного Алтая. В их хозяйственном комплексе соединились охота и собирательство, скотоводство и ручное земледелие.

Выращенные на небольших полях на горных склонах зерна ячменя или пшеницы перемалывались на таких зернотерках в крупу или муку. А еще на таких камнях перетирали высушенные плоды черемухи и измельчали крупную соль. Такие каменные зернотерки имелись у кумандинцев, тубаларов, шорцев, челканцев и др. народов Южной Сибири.

У кумандинцев нижний массивный камень и назывался пасак, а верхний маленький камень-курант именовался пасакпаласэ. Для повышения выработки на рабочих частях нижнего и верхнего камней топором наносились поперечные насечки.

На зернотерке трудились женщины. Чтобы получить муку тонкого помола, зерна и крупу пропускали через камни несколько раз. Из крупных частиц поджаренных ячменных зерен готовили талкан - крупу, которую добавляли в чай и разные похлебки. Из муки готовили тесто для пельменей (бэльмене) и лапши (тутпаш), а также пекли сдобные изделия и хлеб.

Каменные зернотерки можно и сегодня встретить в некоторых кумандинских семьях, где они используются по прямому назначению. В кумандинском этноцентре в с. Красногорском туристам обязательно предложат мастер-класс по работе на пасак!

На нашей выставке зернотерка представлена вместе с талканом, который летом прошлого года я приобрел на кумандинском фестивале в с. Красногорском. Часть талкана я отсыпал на выставку, а оставшееся добавляю в свой чай. С талканом, как известно, чай становится гораздо вкуснее!»

История пятая «Деревянная ступа соко»,

7 апреля 2020 г.

На выставке «Мир таежных культур Северного Алтая» самый массивный экспонат - деревянная ступа. Она, конечно, не такая большая, как это изображается в сказках, и волшебный персонаж пенсионного возраста в ней полетать не сможет. Хотя никто не проверял, что происходит с экспонатами в музее по ночам. Быть может, кто-то на этой ступе в сумерках и летает...

Наша музейная ступа чуть больше метра в высоту. Ее мы обнаружили в 2001 г. в кумандинской семье в с. Ужлеп в Красногорском районе Алтайского края. В своем полевом дневнике нахожу запись об этой ступе и фото ее владелицы Раисы Ахметовны Тырышевой, которая тогда и подарила этот предмет в наш Музей археологии и этнографии Алтая АлтГУ.

Ступа на кумандинском языке соко. Она изготовлена в технике выдалбливания из полубревен, которые по завершении обработки были вместе скреплены железным обручами. В таких ступах обмолачивали и толкли зерна, готовили крупу, измельчали сухие плоды и т. д. Она - неотъемлемое орудие обработки земледельческой и собирательской продукции.

В своем фотоархиве нахожу изображения и других ступ, которые в самом начале XXI в. встречались нам во время этнографических поездок в села Турочакского района Республики Алтай, где живут тубалары и челканцы.

Эти ступы изготавливали из осины или тополя как долблением, так и выжиганием. Песты к этим ступам, которыми и производились удары по зернам, также делались из дерева. Как видно на фото, другие ступы уступают в размерах нашему музейному экспонату. Крупный сказочный персонаж для полета в них точно бы не поместился, а вот гном какой-нибудь или леприкон - вполне возможно...»

Таким образом, в современных реалиях организация небольших и мобильных этнографических выставок по разным темам может стать основным направлением деятельности музейных учреждений. Актуальные темы таких выставок, как показывает практика, привлекает внимание общественности и СМИ. В условиях глобальных вызовов, таких, например, как пандемия, небольшие выставочные проекты легко преобразуются, приобретают новые функции и переводятся на альтернативные площадки, в том числе и виртуальные. Важным аспектом такой выставочной деятельности в настоящее время становится активное их продвижение в интернет пространстве, в том числе и в популярных социальных сетях.

\section{I. Nazarov}

\section{Ethnographic exhibition in the modern museum space of Barnaul}

Annotation. The publication presents the experience of organizing and conducting ethnographic exhibitions at various venues in the city of Barnaul. The exhibitions were held in two main thematic areas. The first direction is associated with the presentation of the collection of traditional hats of the peoples of the world from the collection of the author of this publication. The second direction updated the ethnographic collection on the culture of the indigenous peoples of Northern Altai from the funds of the Museum of Archeology and Ethnography of Altai, Altai State University. The exhibitions received positive responses from various groups of visitors and were widely consulted in various media. The success of the exhibitions was also associated with their active promotion in social networks. Keywords: ethnography, museum, exhibitions, collecting, hats, Central Asia, Northern Altai.

\section{Источники и литература}

1. Выставку головных уборов разных народов готовят к открытию в Алтайском крае // Официальный сайт
Администрации Алтайского края [Электронный реcypc].URL:https://www.altairegion22.ru/region_news/ 
vystavku-golovnyh-uborov-raznyh-narodov-gotovyatk-otkrytiyu-v-altaiskom-krae_725874.html?sphrase $\mathrm{id}=969149$ (дата обращения: 05.04.2020).

2. В Алтайском краеведческом музее открылась выставка из коллекции ученого-этнографа АлтГУ // Сайт Алтайского государственного университета [Электронный ресурc]. URL: https://www.asu.ru/ news/events/30677/?fbclid=IwAR32UePbwOrWhaOw0hjW4nHj7EgIEBMrHgIsWxEOJnJsCnNTUUd4sc0xB8 (дата обращения: 05.04.2020).

3. Выставка «Все дело в шляпе» // Сайт «Культура.рф» [Электронный pecypc]. URL: https://www.culture.ru/ events/362705/vystavka-vse-delo-v-shlyape?fbclid=I wAR0ho9IWnZmTwdmfgHSvSsKm5CAzefShDlt3CY2t U7Q_5dbp3Byjeb7dXgY (дата обращения: 05.04.2020).

4. Николаева Е. Шапки по Сеньке, Ахмеду, Гиви. Необычная выставка открылась на Алтае // Аргументы и факты. № 43. «АиФ - Алтай». 2018. 24 окт.

5. Герасимов В. Смотрю - шляпа, пригляделся самбреро... // Алтайская правда. 2018. 27 окт.

6. Ермошина С. Дело в шляпе. В краеведческом музее открылась выставка головных уборов // Вечерний Барнаул. 2018. 23 окт. Алтай. 2018. 24 окт.

7. Шабалин А. Все дело в шляпе // За науку. 2018. 25 окт.

8. Радио ГТРК «Алтай»: головные уборы из частной коллекции ученого АлтГУ выставили в краеведческом музее // Сайт Алтайского государственного университета [Электронный ресурс]. URL: https://www.asu.ru/news/press/30657/?fbclid= IwAR1s1pcjThlkI23PMbewMSuV4-0CYX8Wj9ALaMPk y7ImATuIQT-Tgu-emGQ (дата обращения: 05.04.2020).

9. Выставку национальных головных уборов народов Центральной Азии представят в столице Алтайского края // Официальный сайт Администрации Алтайского края [Электронный ресурс]. URL: https://www.altairegion22.ru/region_news/ vystavku-natsionalnyh-golovnyh-uborov-narodovtsentralnoi-azii-predstavyat-v-stolitse-altaiskogokraya_759537.html?sphrase_id=969149 (дата обращения: 05.04.2020).

10. Уникальная выставка из частной коллекции ученого АлтГУ готовится к открытию в Барнауле // Сайт Алтайского государственного университета [Электронный ресурc]. URL: https://www.asu.ru/news/ press/32007/?fbclid=IwAR0-20aE7a7QurwvbcD6IGH0 K6IGMyJiVnf43xWVLecEK5vdllPMXXr3j3I (дата обращения: 05.04.2020).

11. «Из сердца Азии». Выставка национальных головных уборов народов Центральной Азии // Сайт Алтайского краевого Российско-немецкого дома [Электронный ресурc]. URL: http://ak-rnd.org/ novosti/post/iz-serdtsa-azii-vystavka-natsionalnykhgolovnykh-uborov-narodov-tsentralnoy-azii?last url=\%2F\&fbclid=IwAR2wWguh5Bln_nAjQ8oVzkdOoS pLJHURURH9aUlvH1ucEeJd2oaIaAkpbFE (дата обращения: 05.04.2020).

12. «Из сердца Азии: символика национальных головных уборов» // Сайт Алтайского краевого Российско-немецкого дома [Электронный ресурc]. URL: http://ak-rnd.org/anonsy/news_post/iz-serdtsa-aziisimvolika-natsionalnykh-golovnykh-uborov?fbclid=Iw
AR1FVSy6AL5MaaqQetQWUjgBVEh9mL6mzukaQII83 qdjMqjq9VOzRYWRHJ4 (дата обращения: 05.04.2020).

13. В Барнауле открыли выставку азиатских головных уборов // Сайт издательского дома «Алтапресс» [Электронный ресурс]. URL: https://altapress. $\mathrm{ru} /$ afisha/story/v-barnaule-otkrili-vistavku-aziatskihgolovnih-uborov-237574?fbclid=IwAR1 qay-ltAmEWiS43kvg-sf4CriRnUb8o7MpPMYF78GNGkynrErzZOh_ ss (дата обращения: 04.04.2020).

14. Азия на голове // За науку. 2019. 14 февр.

15. Назаров И. И. «Из сердца Азии» - уникальный выставочный проект о национальных головных уборах в г. Барнауле // Россия многонациональная. Алтайский край. 2019. С. 32-35.

16. Продлена выставка «Из сердца Азии: символика национальных головных уборов» // Сайт Алтайского краевого Российско-немецкого дома [Электронный pecypc]. URL: https://barnaul.org/news/v-barnaulegotovyat-dve-etnograficheskie-vystavki.html?fbclid= IwAR1sX5oCGLBWF_otCUFQmnHLYGHWQPB2SYL I6GdkKrxR8f1ct5Vxg-ȲZ-c (дата обращения: 05.04.2020).

17. Абрамова Ю. Стратегическая сессия: сила в сотрудничестве // За науку. 2020. 6 февр.

18. Барнаульцы смогут увидеть две этнографических выставки // Аргументы и факты. АИФ - Алтай. [Электронный ресурc]. URL: https://altai.aif.ru/society/ barnaulcy_smogut_uvidet_dve_etnograficheskie_ vystavki (дата обращения:05.04.2020).

19. В Барнауле готовят две этнографические выставки // Официальный сайт Администрации города Барнаула [Электронный ресурс]. URL: https://barnaul. org/news/v-barnaule-gotovyat-dve-etnograficheskievystavki.html? fbclid=IwAR1s X 5 o CGLBWF_ otCUFQmn HLYGHWQPB2SYL_I6GdkKrxR8f1ct5VxgYZ-с (дата обращения: 05.04.2020).

20. Две этнографических выставки откроют в Барнауле // Катунь24. Краевой общедоступный канал [Электронный ресурc]. URL: https://katun24.ru/ news/593315 (дата обращения 05.04.2020).

21. Две этнографических выставки откроют в столице Алтайского края // Официальный сайт Администрации Алтайского края [Электронный ресурс]. URL: https://www.altairegion22.ru/region_news/dveetnograficheskie-vystavki-otkroyut-v-stolitsealtaiskogo-kraya_835075.html?sphrase_id=969149 (дата обращения: 05.04.2020).

22. Две этнографические выставки приступили к работе в АлтГУ (видео) // Сайт Алтайского государственного университета [Электронный ресурc]. URL: https:// www.asu.ru/news/events/35955/?fbclid=IwAR1oM_ AGeBlZreUTxNFjCDUOTvnUBzzQY_GVklXzMhxnVzu hkL9ThWidx9k (дата обращения: 05.04.2020).

23. Славнин В. Д. Коротко об экспедициях // Советская этнография. 1978. № 1. С. 161-162.

24. Бельгибаев Е. А., Назаров И. И. Этнографические экспедиции АлтГУ 2000-2005 гг: из опыта полевой работы // Полевые исследования в Верхнем Приобье и на Алтае 2006 г.: археология, этнография, устная история. Вып. 3: материалы III региональной научно-практической конференции, Барнаул, 6-8 дек. 2006 г. / редкол.: М. А. Демин, Т. К. Щеглова, А. Н. Телегин. Барнаул: БГПУ, 2007. С. 90-95. 
25. Назаров И. И. Этнографические коллекции Музея археологии и этнографии Алтая Алтайского государственного университета // Этнография Алтая и сопредельных территорий:материалы научно-практической конференции. Барнаул, 2005. С. 214-215.

26. Марьин Д. Задача для вузов // Российская газета. 2019. № 281.

27. Состоялось открытие первого в истории АлтГУ этнографического музейного проекта // Сайт «Алтайский государственный университет» [Электронный ресурc]. URL: https://www.asu.ru/news/ events/35933/?fbclid=IwAR13wMtFs-M9CwQgyhR
hSC-GT1wHkCb8OYOkKjqnczlF2Gd9pupDDp6Kss（дата обращения: 05.04.2020).

28. В музейном зале // За науку. 2020. 30 янв.

29. Загадки Северного Алтая // За науку. 2020. 13 февр.

30. Ведерникова О. В Барнауле можно увидеть и потрогать фигурку древнего духа Шалыга // Комсомольская правда. Барнаул [Электронный ресурс]. URL: https://www.alt.kp.ru/daily/27098/4171974/ (дата обращения: 05.04.2020).

31. Алексеев Р. История из бабушкиного сундука // Аргументы и факты. АИФ - Алтай. 2020. № 8 (19 февр.).

32. Олексюк И. Лыжи на меху и дух Шалыга // Комсомольская правда. Барнаул. 2020. 19 февр.

УДК 39(=161.1)

DOI 10.37386/2687-0592-2020-10-350-357

\title{
Е. А. Полякова
}

Барнаульский юридический институт МВД России, Алтайский государственный институт культуры, г. Барнаул, Российская Федерация

\section{Музейно-этнографические программы как способ сохранения национальной идентичности (на примере деятельности Омского государственного музея-заповедника «Старина Сибирская»)}

\begin{abstract}
Аннотация. Сохранение национальной и этнической идентичности граждан является важной задачей, стоящей перед российским государством в условиях глобализации и вестернизации. Унификация национальных культур и формирование монокультурного мира приводит к деактуализации наследия традиционных культур. Музей как уникальный инструмент реализации образовательно-воспитательной и культурной политики государства участвует в формировании актуальной идеологической парадигмы общества, обязательной частью которой является национальная идентичность. Особым потенциалом в обладают провинциальные музеи краеведческой и этнографической направленности, в основе коммуникативной деятельности которых лежит концепция «живого музея». Их коммуникация, основанная на реализации образовательных, воспитательных, творческих и рекреационных музейно-этнографические программ, является востребованной и актуальной в контексте задач, поставленных государственной культурной политикой. Омский государственный музей-заповедник «Старина Сибирская» является ярким представителем «живого музея», реализующим музейно-этнографические программы и являющимся заметным явлением в музейном пространстве Западной Сибири. Ключевые слова: национальная идентичность, этническая идентичность, государственная культурная политика, традиционная культура, «живой музей», музейно-этнографические программы, Омский государственный музей заповедник «Старина сибирская».
\end{abstract}

Сохранение национальной и этнической идентичности граждан - важная задача, стоящая перед каждым государством. В отечественной литературе под идентичностью понимается «осознание человеком своей принадлежности к какой-либо группе, позволяющее ему определить свое место в социокультурном пространстве и свободно ориентироваться в окружающем мире» [1, с. 24-25], «осознание себя частью определенной моноэтнической составляющей, имеющей отличительные от других этнических групп черты» [1, с. 34], «чувство неразрывности с прошлым, чувство самоопределения человека» [3, с. 24]. Компонентами, формирующими нацио-

1 «При подготовке публикации использованы материалы гранта РФФИ, проект 14-06-98003 р_сибирь_а «Научные основы интеграции культурно-исторического наследия в сферу туризма. Региональный аспект на примере Алтайского края». нальную идентичность, являются «национальное самосознание и менталитет, национальный характер, историческая память, этнонациональные образы, национальные традиции» [3, с. 25]. Причины кризиса национальной и этнической идентичности, по мнению К. Ф. Катковой, связаны «с внутренними перестроечными явлениями, приведшими к разрушению базовых структур на экономическом, политическом и культурном уровне, уничтожением ценностей советской идентичности и утратой связей с традициями российского государства, так и с общемировой ситуацией, связанной с нивелирующим воздействием глобализации и общемировым экономическим кризисом, приведшим к снижению роли государства, стандартизации образа жизни» [2, с. 35].

В России проблемы национально-культурной и этнической идентичности обострили процессы глобализации и вестернизации, вследствие которых отечественное социокультурное пространство ста- 